\title{
Effects of Galactose Feeding on Aldose Reductase Gene Expression
}

Ruth R. Wu, Paul A. Lyons, Agnes Wang, Amanda J. Sainsbury, Stephen Chung, ${ }^{*}$ and T. Norman Palmer Department of Biochemistry, University of Western Australia, Nedlands, Western Australia 6009, Australia; and *Institute of Molecular Biology, Hong Kong

\begin{abstract}
Aldose reductase (AR) is implicated in the pathogenesis of the diabetic complications and osmotic cataract. AR has been identified as an osmoregulatory protein, at least in the renal medulla. An outstanding question relates to the response of $\mathbf{A R}$ gene expression to diet-induced galactosemia in extrarenal tissues. This paper shows that AR gene expression in different tissues is regulated by a complex multifactorial mechanism. Galactose feeding in the rat is associated with a complex and, on occasions, multiphasic pattern of changes in AR mRNA levels in kidney, testis, skeletal muscle, and brain. These changes are not in synchrony with the temporal sequence of changes in tissue galactitol, galactose, and myoinositol concentrations. Moreover, galactose feeding results in changes in tissue AR activities that are not related, temporally or quantitatively, to the alterations in tissue AR mRNA or galactitol levels. It is concluded that $A R$ gene expression and tissue $A R$ activities are regulated by mechanisms that are not purely dependent on nonspecific alterations in intracellular metabolite concentrations. This conclusion is supported by the finding that chronic xylose feeding, despite being associated with intracellular xylitol accumulation, does not result in alterations in AR mRNA levels, at least in the kidney. (J. Clin. Invest. 1993. 92:155-159.) Key words: diabetes mellitus • ducitol • galactose • galactosemia • sugar alcohol dehydrogenase
\end{abstract}

\section{Introduction}

Aldose reductase $\left(\mathrm{AR}^{1}\right.$; polyol; $\mathrm{NADP}^{+} 1$-oxidoreductase, $\mathrm{EC}$ 1.1.1.21), which reduces aldoses and other aldehydes to their corresponding alcohols, is recognized to play a central role in the genesis of the diabetic complications (1). It is presumed that pathogenesis is initiated by AR-catalyzed sorbitol formation from glucose, a process that is stimulated by the hyperglycemia associated with diabetes. This AR-catalyzed sorbitol formation may be an expression of the physiological function of AR in cellular osmoregulation (reviewed by Burg [2]). Sorbitol may function as an osmolyte and its intracellular accumulation may serve to counterbalance high extracellular osmolality

Address reprint requests to Dr. Ruth Wu, Department of Biochemistry, University of Western Australia, Nedlands, Western Australia 6009 , Australia.

Received for publication 19 October 1992 and in revised form 28 January 1993.

1. Abbreviations used in this paper: ALR, aldehyde reductase; AR, aldose reductase.

J. Clin. Invest.

(c) The American Society for Clinical Investigation, Inc.

$0021-9738 / 93 / 07 / 155 / 05 \quad \$ 2.00$

Volume 92, July 1993, 155-159 and maintain cell volume, particularly in the renal medulla which is exposed to high extracellular sodium chloride concentrations as part of the urinary concentrating mechanism. Dietinduced galactosemia in the rat is associated with the accumulation of the AR-product galactitol in the renal medulla, a reduction in AR mRNA levels, and depletion of renal papillary sorbitol and other osmolytes ( 3 ). These effects are largely abolished by the AR inhibitor sorbinil, implying that intracellular accumulation of AR products ( viz. galactitol) causes down-regulation of AR gene expression. Streptozotocin-induced diabetes is associated with increased renal AR gene expression implying that diabetes-related hyperglycemia and hypertonicity stimulate gene expression $(4,5)$.

Although AR gene expression in lens may be osmoregulated (6), the role of AR in tissues other than the renal medulla is unclear. There is overwhelming evidence that abnormal flux via $A R$ in susceptible tissues is harmful in diabetes and galactosemia. The focus of the present study was the response of AR gene expression to diet-induced galactosemia in a number of different tissues, the aim being to establish whether a unifying osmoregulatory hypothesis can be invoked in all tissues to explain the changes associated with continuous, prolonger galactose feeding. A related question is whether continuous xylose feeding and tissue accumulation of the AR product xylitol is associated with alterations in AR gene expression.

\section{Methods}

Animals. Male Wistar rats $(100 \mathrm{~g})$, maintained on a 12-h light/12-h dark cycle (light from 07:30 h), were fed ad lib. on a standard laboratory diet supplemented with $50 \%(\mathrm{wt} / \mathrm{wt}$ ) galactose by the procedure of Bondy et al. (3). Animals were randomly assigned to four experimental groups, each comprising six rats, and fed on the galactose-supplemented diet for $2,7,14$, or $21 \mathrm{~d}$. A control group (six rats) received unmodified laboratory diet for $21 \mathrm{~d}$. At the end of the feeding periods animals were sampled under halothane anesthesia, samples of kidney, testis, brain, and muscle (thigh and calf) being rapidly frozen in aluminium clamps precooled in liquid nitrogen and stored at $-80^{\circ} \mathrm{C}$ until analyzed. This sampling procedure in live anesthetized rats, which took no more than 5 min per animal, avoids problems associated with postmortem changes in metabolite concentrations and mRNA levels that arise if organs are isolated without freeze-clamping, particularly if they are dissected postmortem into their different anatomical components before biochemical analysis. Intraventricular blood samples were deproteinized in $6 \%(\mathrm{wt} / \mathrm{vol})$ perchloric acid and the supernatants neutralized with $2.8 \mathrm{M} \mathrm{KOH}$. Other rats (six in each experimental group) were fed on standard laboratory diet supplemented with $50 \%$ (wt/wt) xylose for $0,4,7,14$, or $21 \mathrm{~d}$.

Rates of blood clearance of D-galactose were examined in six male Wistar rats $(100 \mathrm{~g})$ fed either on the galactose-supplemented diet or standard laboratory diet for $21 \mathrm{~d}$. Clearance kinetics were determined after an overnight fast under halothane anesthesia. A basal blood sample was taken before the intravenous administration of D-galactose ( 60 $\left.\mathrm{mg} \cdot \mathrm{kg}^{-1}, 200 \mu \mathrm{l}\right)$ from the tail vein. Thereafter serial blood samples were taken from the tail at $3,5,8,12,20,30,40$, and $60 \mathrm{~min}$ and deproteinized with $6 \%(\mathrm{wt} / \mathrm{vol})$ perchloric acid. The supernatants were 
neutralized with $2.8 \mathrm{M} \mathrm{KOH}$. The galactose half-life $\left(t_{50}\right)$ was calculated from the constructed galactose clearance curves.

Analytical methods. Blood concentrations of glucose (7), lactate (8), and galactose (9) were determined in $\mathrm{KOH}$-neutralized perchloric acid extracts by published spectrophotometric methods, except for analysis of blood galactose clearance when galactose was determined luminometrically (10). Measurement of blood galactose by gas liquid chromatography (11) gave similar results to those obtained by the spectrophotometric method. Blood xylose levels were determined as the difference between total blood sugar determined by the phenol-sulfuric acid method (12) and blood glucose levels determined by the glucose oxidase method (7).

Tissue concentrations of galactose, galactitol, xylose, xylitol, and myoinositol were measured by gas liquid chromatography using a modification of the method of Stribling et al. (11). Briefly, tissue samples ( $<200 \mathrm{mg}$ ) were homogenized in $1 \mathrm{ml} 10 \mathrm{mM}$ sodium phosphate buffer, $\mathrm{pH} 7.0$, containing $\alpha$-methylmannoside $\left(0.02 \mathrm{mg} \mathrm{ml}^{-1}\right)$ as an internal standard and boiled for $25 \mathrm{~min}$. After centrifugation $(1,600 \mathrm{~g}$, $20 \mathrm{~min}$ ), the supernatants were dried under vacuum for $3 \mathrm{~h}$ and silylated overnight as described by Stribling et al. (12). The silylated samples partitioned in water $(4 \mathrm{ml})$ and cyclohexane $(0.2 \mathrm{ml})$ were analyzed on a gas chromatograph (model GC-14A, Shimadzu Ltd., Japan) fitted with a fused silica capillary column (25QC3. BP1-0.5). Sugars and polyols were detected by flame ionization (detector temperature $240^{\circ} \mathrm{C}$ ) and tissue concentrations are expressed as microgram per milligram protein, protein concentration being determined by the method of Bradford (13).

It is not possible to specifically determine tissue AR activities because other enzymes, notably aldehyde reductase (ALR), resemble AR in substrate specificity (14). Measurement of DL-glyceraldehyde reductase activities provides an approximate measure of a tissue's total aldoketo reductase capacity (AR + ALR), whereas measurement of galactose reductase activities is an index of the tissue's functional capacity for galactitol formation from galactose and is a relatively specific function of AR. The relative $k_{\mathrm{m}}$ values of AR and ALR for galactose in testis, for example, are $122 \mathrm{mM}$ and $>7,000 \mathrm{mM}$ (15), respectively, implying that $A R$ is the major enzyme responsible for galactitol formation in vivo, except at very high galactose concentrations. AR and related activities were determined spectrophotometrically with either DL-glyceraldehyde or galactose as substrate. Tissues were homogenized in 5-7 vol of ice-cold $100 \mathrm{mM}$ sodium phosphate buffer, $\mathrm{pH} 6.5$, and centrifuged $(45,000 \mathrm{~g}, 40 \mathrm{~min})$ at $4^{\circ} \mathrm{C}$. A portion $(100-200 \mu \mathrm{l})$ of the supernatant was added to a reaction mixture at $37^{\circ} \mathrm{C}$ containing $0.4 \mathrm{M}$ ammonium sulphate and $0.2 \mathrm{mM}$ NADPH in $10 \mathrm{mM}$ sodium phosphate buffer, pH 6.5 , to give a final volume of $1 \mathrm{ml}$. After a 20-min preincubation at $37^{\circ} \mathrm{C}$, the reaction was started by the addition of DLglyceraldehyde (final concentration $10 \mathrm{mM}$ ) or galactose (final concentration $200 \mathrm{mM}$ ) and the absorbance determined at $340 \mathrm{~nm}$ for 2 min. Enzyme activity is expressed as milliunits per milligram of protein, $1 \mathrm{mU}$ being the amount of enzyme that catalyzes the oxidation of $1 \mathrm{nmol}$ NADPH per min at $37^{\circ} \mathrm{C}$.

Total RNA was extracted from kidney, brain, testis, and muscle by the acid-guanidium thiocynate-phenol-chloroform method (16). RNA samples $(15 \mu \mathrm{g})$ were denatured at $50^{\circ} \mathrm{C}$ for $1 \mathrm{~h}$ in a mixture of 1 $\mathrm{M}$ glyoxal (freshly deionized) and $10 \mathrm{mM}$ sodium phosphate buffer, pH 7.0. Denatured RNA samples were electrophoresed in $1.4 \%$ (wt/ vol ) agarose gels ( $120 \mathrm{~mA}$ for $3 \mathrm{~h}, 10 \mathrm{mM}$ sodium phosphate, $\mathrm{pH} 7.0$ ) and transferred to nylon membranes (Hybond-N, Amersham International, Amersham, UK) by capillary blotting as described by Thomas (17). After baking at $80^{\circ} \mathrm{C}$ for $3 \mathrm{~h}$, the filters were prehybridized at $65^{\circ} \mathrm{C}$ for $2 \mathrm{~h}$ in a solution containing $6 \times \operatorname{SSC}(0.9 \mathrm{M} \mathrm{NaCl}, 0.09 \mathrm{M}$ trisodium citrate, $\mathrm{pH} 7.0), 1 \times$ Denhardt's solution $(0.2 \%$ Ficoll, $0.2 \%$ polyvinylpyrrolidone, $0.2 \% \mathrm{BSA}$, and $0.01 \% \mathrm{SDS}$ ), $10 \mathrm{mM}$ sodium phosphate, pH 7.0, 1 mM EDTA, 5\% (wt/ vol) dextran sulfate, and 100 $\mu \mathrm{g} \cdot \mathrm{ml}^{-1}$ denatured herring sperm DNA. Hybridizations were carried out overnight at $65^{\circ} \mathrm{C}$ using a fresh volume of the same solution containing ${ }^{32} \mathrm{P}$-labeled human placental AR cDNA probe (18). Filters were washed at $65^{\circ} \mathrm{C}$ three times with $5 \times$ SSC- $0.1 \%$ (vol/vol) SDS and two times with $2 \times$ SSC $-0.1 \%$ (vol/vol) SDS, each wash for a duration of $15 \mathrm{~min}$, and then exposed to X-OMAT-AR film (Eastman Kodak Co., Rochester, $\mathrm{NY}$ ) at $-80^{\circ} \mathrm{C}$. To determine the relative quantities of AR mRNA, the blots were stripped with a solution of $50 \%$ ( vol $/ \mathrm{vol})$ formamide and $10 \mathrm{mM}$ sodium phosphate, $\mathrm{pH} 7.0$, at $65^{\circ} \mathrm{C}$ for $1 \mathrm{~h}$, washed three times with $2 \times$ SSC $-0.1 \%$ SDS for 10 min each time, and rehybridized under the conditions described above with a glyceraldehyde 3-phosphate dehydrogenase cDNA probe. Autoradiographs were quantified by densitometry and AR mRNA levels expressed as a ratio to the levels of glyceraldehyde 3-phosphate mRNA.

Statistical analysis. Data were analyzed by the one-way ANOVA test and results are expressed as means \pm SEM with the number of animals in parentheses.

\section{Results}

Response of $A R$ to galactose feeding. Diet-induced galactosemia and the associated accumulation of the AR product galactitol causes down-regulation of AR gene expression, providing a mechanism of cellular osmoregulation (3). An important question is whether this presumed mechanism of cellular osmoregulation functions in tissues other than the kidney and whether galactose feeding causes parallel changes in AR gene expression in these tissues. Galactose feeding is associated with a complex pattern of changes in AR mRNA levels that varies between tissues (Fig. 1). The response of renal AR mRNA levels to galactose feeding is biphasic. There is an initial decline -by $11 \%$ at day $2(P<0.01)$, and by $>30 \%$ at days $7(P$ $<0.001)$ and $14(P<0.01)$-followed by a massive increase in mRNA levels to $266 \%$ of basal at $21 \mathrm{~d}(P<0.001)$. In contrast, testicular AR mRNA levels show a sustained decline (by $26 \%$ at day 2 and by $\sim 50 \%$ thereafter; $P<0.001$ ), whereas brain AR mRNA levels increase after $2 \mathrm{~d}$ of galactose feeding (by $20 \% ; P<0.01$ ) and thereafter decline (by $>30 \% ; P<0.01$ ). The response of muscle AR mRNA levels is multiphasic: levels initially decrease (by $36 \%$ at days 2 and $7 ; P<0.001$ ), then return to basal at $14 \mathrm{~d}$ and thereafter decline (by $36 \% ; P$ $<0.001$ ).

An important question concerns the extent to which alterations in AR mRNA levels, associated with galactose feeding, cause alterations in tissue AR activities. Whereas tissue glyceraldehyde reductase activities remain constant in response to continuous galactose feeding (results not shown), galactosemia is associated with changes in tissue galactose reductase activities ( Table I). An important finding is that the changes in AR mRNA levels in response to galactose feeding are not accompanied by parallel changes in the tissue activities of galactose reductase. Although these activities may change in response to galactose feeding, the changes are neither in synchrony with nor can be related to alterations in AR mRNA levels. The ratio of galactose reductase activity to AR mRNA levels varies markedly between tissues and there is no linear relationship between either tissue galactose reductase or glyceraldehyde reductase activities and AR mRNA levels $(P>0.05$ in all instances).

Response of tissue polyols and sugars to galactose feeding. It is important to establish to what extent the changes in AR mRNA levels and enzyme activities in response to galactose feeding are determined by changes in tissue polyol concentrations. Continuous galactose feeding is associated with galactosemia without any accompanying alterations in blood glucose $(4.6 \pm 0.2 \mathrm{mM})$ and lactate $(1.2 \pm 0.1 \mathrm{mM})$ levels (Table II). A consistent finding was that blood galactose levels were elevated 

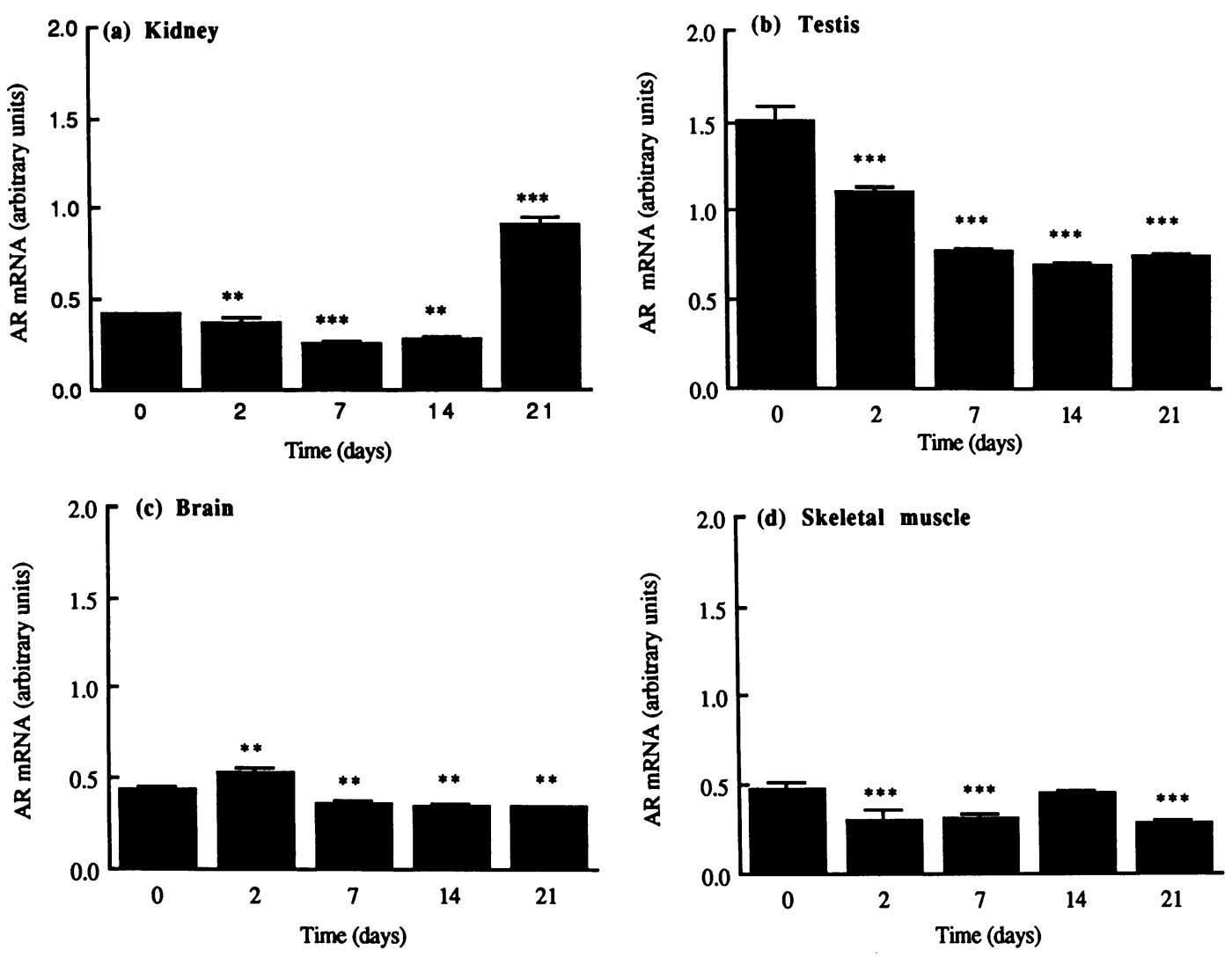

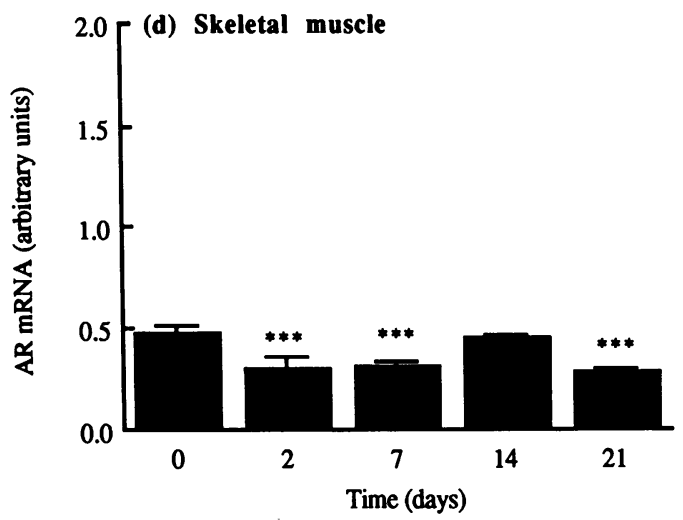

Figure 1. The effects of different durations of galactose feeding on levels of AR mRNA in $(a)$ kidney, $(b)$ testis, $(c)$ brain, and $(d)$ skeletal muscle. Autoradiographs of Northern blots were quantified by densitometry and AR mRNA levels expressed (in arbitrary units) as a ratio to the levels of glyceraldehyde 3-phosphate dehydrogenase mRNA. Statistically significant differences between day 0 and other days of feeding are denoted as ${ }^{* *} P<0.01$; ${ }^{* * *} P<0.001$. (by $172 \%$ ) at $14 \mathrm{~d}$ and thereafter declined. In agreement with others, tissue galactitol levels increase as a function of the duration of feeding and this abnormal accumulation is most pronounced in skeletal muscle (19). Relative tissue galactitol accumulation in response to galactose feeding is skeletal muscle $>$ testis $>$ brain $>$ kidney (Table III). Except in kidney, these differences between tissues in the extent of galactitol accumulation are not related to differences in tissue galactose levels. If tissue galactitol levels were to be determined solely by tissue AR activities, a relationship would be predicted between AR activity and the extent of tissue galactitol accumulation. No such relationship exists implying that galactitol accumulation is not a simple function of either AR activity or AR gene expression. For example, although the testis possesses substan-

Table I. Galactose Reductase Activity in Tissues from Galactose-fed Rats

\begin{tabular}{lrccc}
\hline & \multicolumn{4}{c}{ Duration of galactose feeding } \\
\cline { 2 - 5 } Tissue ( $n$ ) & \multicolumn{1}{c}{ Day 0 } & Day 7 & Day 14 & Day 21 \\
\hline \multicolumn{5}{c}{$m U / m g$ protein } \\
Kidney (6) & $4.3 \pm 0.4$ & $3.2 \pm 0.1$ & $3.1 \pm 0.1^{\ddagger}$ & $2.4 \pm 0.1^{\ddagger}$ \\
Testis (6) & $26.7 \pm 2.1$ & $42.0 \pm 3.8^{*}$ & $30.0 \pm 3.7$ & $7.8 \pm 0.7^{\ddagger}$ \\
Brain (6) & $1.6 \pm 0.1$ & $1.5 \pm 0.1$ & $1.8 \pm 0.3$ & $1.4 \pm 0.1$ \\
Muscle (6) & $2.0 \pm 0.2$ & $2.0 \pm 0.3$ & $2.0 \pm 0.1$ & $2.2 \pm 0.2$ \\
\hline
\end{tabular}

The data are shown as means \pm SEM with the number of rats shown in parentheses. ${ }^{*}$ Significantly different from day $0, P<0.01$ by ANOVA. ${ }^{\ddagger}$ Significantly different from day $0, P<0.001$ by ANOVA. tially higher levels of galactose reductase activity than skeletal muscle, galactitol concentrations are up to almost fourfold higher in muscle. Consistent with the medullary localization of AR, levels of galactose and galactitol in the intact kidney ( Table III) are significantly less (by $>20$-fold) than those reported by Bondy et al. in renal papillae from rats fed on a galactosesupplemented diet for $10 \mathrm{~d}(3)$.

Galactose feeding is reported to be associated with the depletion of myoinositol in the rat inner renal medulla (3). Table III indicates a more complex multiphasic pattern of changes that varies between the different tissues. Although short-term ( $2 \mathrm{~d})$ feeding is indeed associated, except in skeletal muscle, with decreased tissue myoinositol levels, extended feeding, at least in muscle, brain and kidney, causes first an elevation and then a reduction in tissue myoinositol levels.

Effects of galactose feeding on galactose clearance. Alterations in tissue AR activities may alter the capacity of specific

Table II. Blood Metabolite Concentrations

\begin{tabular}{lccccc}
\hline & \multicolumn{5}{c}{ Duration of galactose feeding } \\
\cline { 2 - 6 } Metabolite & Day 0 & Day 2 & Day 7 & Day 14 & Day 21 \\
\hline & & $m M$ \\
Galactose & 0 & $2.2 \pm 1.1^{*}$ & $6.5 \pm 1.2^{\ddagger}$ & $17.7 \pm 0.7^{\ddagger}$ & $5.2 \pm 1.5^{\ddagger}$ \\
Lactate & $1.1 \pm 0.1$ & $1.0 \pm 0.3$ & $1.2 \pm 0.2$ & $1.5 \pm 0.2$ & $1.2 \pm 0.1$ \\
Glucose & $4.4 \pm 0.4$ & $4.2 \pm 0.3$ & $4.7 \pm 0.2$ & $4.5 \pm 0.3$ & $5.4 \pm 0.3$ \\
& & & & &
\end{tabular}

The values shown are means \pm SEM for six rats. * Significantly different from day $0, P<0.05$ by ANOVA. ${ }^{\ddagger}$ Significantly different from day $0, P<0.001$ by ANOVA. 
Table III. Galactitol, Galactose, and Myoinositol Levels in Tissues from Galactose-fed Rats

\begin{tabular}{|c|c|c|c|c|c|c|}
\hline \multirow[b]{2}{*}{ Tissue $(n)$ polyol } & & \multicolumn{5}{|c|}{ Duration of galactose feeding } \\
\hline & & Day 0 & Day 2 & Day 7 & Day 14 & Day 21 \\
\hline & & \multicolumn{5}{|c|}{$\mu g / m g$ protein } \\
\hline \multirow[t]{3}{*}{ Kidney (6) } & galactitol & 0 & $2.4 \pm 0.9$ & $3.9 \pm 0.6$ & $4.9 \pm 0.5^{\ddagger}$ & $7.1 \pm 0.7^{\S}$ \\
\hline & galactose & 0 & $6.0 \pm 1.1$ & $8.5 \pm 1.9$ & $10.8 \pm 1.5$ & $51.6 \pm 17.7^{\ddagger}$ \\
\hline & myoinositol & $4.6 \pm 1.7$ & $2.7 \pm 0.3$ & $7.8 \pm 1.8$ & $12.3 \pm 1.9^{* *}$ & $8.7 \pm 0.7^{\| 1}$ \\
\hline \multirow[t]{3}{*}{ Testis (6) } & galactitol & 0 & $12.3 \pm 1.3$ & $18.4 \pm 2.7$ & $12.9 \pm 1.8$ & $20.7 \pm 3.8^{*}$ \\
\hline & galactose & 0 & $1.0 \pm 0.2$ & $3.3 \pm 0.6$ & $14.3 \pm 2.0^{8}$ & $5.6 \pm 0.8^{*}$ \\
\hline & myoinositol & $8.5 \pm 0.8$ & $4.8 \pm 1.6$ & $14.4 \pm 2.0$ & $14.8 \pm 2.0$ & $24.1 \pm 3.0^{\prime}$ \\
\hline \multirow[t]{3}{*}{ Muscle (6) } & galactitol & 0 & $20.4 \pm 3.5$ & $41.4 \pm 6.8^{\S}$ & $46.4 \pm 3.2^{\S}$ & $68.6 \pm 3.2^{\S}$ \\
\hline & galactose & 0 & $17.0 \pm 1.7$ & $15.4 \pm 1.6$ & $16.6 \pm 2.3$ & $19.2 \pm 2.7$ \\
\hline & myoinositol & $0.7 \pm 0.1$ & $1.0 \pm 0.4$ & $2.4 \pm 1.0^{\prime}$ & $0.8 \pm 0.2$ & $0.6 \pm 0.1$ \\
\hline \multirow[t]{3}{*}{ Brain (6) } & galactitol & 0 & $5.2 \pm 0.7$ & $11.4 \pm 1.4^{\ddagger}$ & $11.9 \pm 1.7^{\S}$ & $12.4 \pm 0.9^{\S}$ \\
\hline & galactose & 0 & $6.1 \pm 0.2$ & $6.0 \pm 0.5$ & $5.9 \pm 0.8$ & $8.9 \pm 2.2$ \\
\hline & myoinositol & $8.0 \pm 1.6$ & $1.9 \pm 0.3^{\prime}$ & $8.6 \pm 1.3$ & $10.3 \pm 1.4$ & $8.1 \pm 1.0$ \\
\hline
\end{tabular}

The data are shown as means \pm SEM with the number of rats shown in parentheses. ${ }^{*}$ Significantly different from day $2, P<0.05$ by ANOVA. ${ }^{\ddagger}$ Significantly different from day $2, P<0.01$ by ANOVA. ${ }^{\S}$ Significantly different from day $2, P<0.001$ by ANOVA. "Significantly different from day $0, P<0.05$ by ANOVA. 'Significantly different from day $0, P<0.01$ by ANOVA. ${ }^{* *}$ Significantly different from day $0, P<0.001$ by ANOVA.

tissues for galactose metabolism and in theory may modify whole-body galactose clearance kinetics. It is of interest that the half-life of intravenously administered galactose was decreased $(P<0.05)$ by continuous galactose feeding for $21 \mathrm{~d}$ from $8.6 \pm 1.0$ to $5.8 \pm 0.8 \mathrm{~min}$.

Effects of xylose feeding on renal $A R m R N A$ and polyol levels. Continuous xylose feeding for up to $21 \mathrm{~d}$, which is associated with xylemia (blood xylose $2.1 \pm 0.2 \mathrm{mM}$ ) but unaltered blood glucose concentrations, results in the renal accumulation of xylose and xylitol. Tissue xylose concentrations are increased at $4 \mathrm{~d}$ and remain constant thereafter, whereas xylitol levels increase progressively (Table IV). Despite these profound changes in tissue metabolite concentrations, AR mRNA levels are unaffected by xylose feeding.

\section{Discussion}

The function of AR in tissues other than the renal medulla is unknown, although there is overwhelming evidence that abnormal flux via AR is implicated in the pathogenesis of the diabetic complications and osmotic cataract (1). Continuous galactose feeding, which is associated with renal medullary galactitol accumulation, leads to a reduction in AR mRNA levels consistent with galactitol-mediated down-regulation of renal medullary AR gene expression. An important question is whether this mechanism operates in other tissues.
Prolonged exposure to galactose is recognized to be associated with metabolic adaptation $(20,21)$, which is presumably the basis for the increase in galactose clearance and reduced galactosemia seen at $21 \mathrm{~d}$. The profound alterations in AR mRNA levels in kidney, testis, skeletal muscle, and brain may be one facet of this adaptation. These alterations, except in the case of testis, are not in synchrony with the temporal sequence of changes in total tissue galactitol, galactose, and myoinositol concentrations, nor do they parallel the changes in blood galactose concentrations. The accumulation of these metabolites is indicative of intracellular hyperosmolality, although it must be recognized that intracellular metabolite concentrations may vary significantly between different cell types in complex tissues like the kidney, testis, and brain: It is well recognized that there are regional differences in polyol levels that reflect the cellular localization of aldose reductase. Although, as reported by others (3), short-term galactose feeding is associated with a diminution in renal AR mRNA levels, extended feeding $(21 \mathrm{~d})$ causes a massive increase in mRNA levels ( to $216 \%$ of controls) despite sustained accumulation of galactitol, galactose, and myoinositol. In brain and skeletal muscle, by contrast, the response of AR mRNA levels to chronic galactosemia is complex and multiphasic despite high galactitol levels. These findings, therefore, point to a more complex relationship between galactosemia and AR gene ex-

Table IV. Renal Xylose, Xylitol, and AR mRNA Levels in Xylose-fed Rats

\begin{tabular}{|c|c|c|c|c|c|}
\hline & \multicolumn{5}{|c|}{ Duration of xylose feeding } \\
\hline & Day 0 & Day 4 & Day 7 & Day 14 & Day 21 \\
\hline Xylose ( $\mu$ g mg protein ${ }^{-1}$ ) & 0 & $3.8 \pm 1.0^{*}$ & $5.8 \pm 0.6^{*}$ & $5.0 \pm 0.7^{*}$ & $4.2 \pm 1.1^{*}$ \\
\hline Xylitol ( $\mu$ mg protein $\left.{ }^{-1}\right)$ & 0 & $0.4 \pm 0.1^{*}$ & $0.3 \pm 0.1^{*}$ & $0.6 \pm 0.2^{*}$ & $2.5 \pm 0.3^{*}$ \\
\hline AR mRNA (ratio to GAPDH) & $0.6 \pm 0.1$ & $0.6 \pm 0.1$ & $0.5 \pm 0.5$ & $0.6 \pm 0.1$ & $0.6 \pm 0.1$ \\
\hline
\end{tabular}

The values shown are means \pm SEM for six rats. * Significantly different from day $0, P<0.001$ by ANOVA. 
pression than one based simply on cellular osmoregulation. This conclusion is supported by the finding that chronic xylose feeding, which causes xylemia and substantial tissue xylitol accumulation, is not associated with elevated AR mRNA levels, at least in the kidney. The differential effects of xylose and galactose feeding on AR gene expression are consistent with a regulatory mechanism that is substrate specific as opposed to one that is purely dependent on nonspecific alterations in intracellular organic osmolyte concentrations. This specificity may relate to differences in metabolism between xylose and galactose. Xylose is metabolized exclusively via AR, whereas galactose is metabolized predominantly via the hepatic galactokinase pathway and only to a limited extent via AR.

Whereas others have reported that renal papillary myoinositol levels are reduced in response to diet-induced galactosemia as part of the cellular homeostatic response to elevated galactitol levels (3), the present study indicates a pattern of changes that is complex and multiphasic and varies between tissues. Although short-term galactose feeding ( $2 \mathrm{~d}$ ) is associated with myoinositol depletion in the kidney, testis, and brain, extended feeding results in a secondary increase to levels that may exceed those in the basal state. In skeletal muscle, by contrast, galactose feeding causes an initial increase in myoinositol levels followed a decline to near-basal concentrations. The osmoregulatory accumulation of myoinositol occurs by active transport and it has been presumed that the cytoplasmic ionic strength, which is influenced by external hyperosmolality and intracellular galactitol accumulation, modulates renal medullary myoinositol levels via effects on efflux and influx. This interpretation is put into question by our finding that the relationship between galactitol and myoinositol levels is not reciprocal.

Implicit in the determination of tissue AR mRNA levels in this and other studies is the assumption that mRNA levels reflect transcriptional rates and are related to tissue levels of AR and $A R$ activities. This assumption is put into question by the finding that there is no consistent quantitative or temporal relationship between tissue galactose reductase activities and AR mRNA levels. Although this anomaly may be explained in part by the multisubstrate specificities of AR and related enzymes, particularly ALR, it does imply that factors other than AR mRNA levels, notably AR turnover and enzyme activation (22), may determine tissue enzyme activities. Measurement of tissue levels of immunoreactive $A R$ in relation to $A R$ activities is necessary to establish the extent to which posttranslational events determine cellular AR activities. In this context, it is noteworthy that continuous galactose feeding produces increases in levels of both AR mRNA and immunoreactive AR in rat lens $(23,24)$.

Emphasis in the literature hitherto has been on the role of $\mathrm{AR}$ in relation to cellular osmoregulation. This article reports a complexity of regulation of tissue AR and AR mRNA levels that is incompatible with osmoregulation as the exclusive mechanism governing polyol metabolism. The implication is that other factors, one of which may be sugar-specific, contribute to the regulation of the cellular activity of the polyol pathway. An important question relates to why AR gene expression needs to be regulated by factors other than cytoplasmic ionic strength. One reason may relate to a physiological role of $A R$ in sugar metabolism: The modulation of AR activities may constitute an important component of the body's capacity to metabolise dietary aldoses and alterations in AR activities may be one factor in the adaptive increase in galactose clearance rates in diet-induced galactosemia.

\section{Acknowledgments}

The support of the Raine Medical Research Foundation, the Diabetes Research Foundation of Western Australia and the Rebecca L. Cooper Medical Research Foundation is gratefully acknowledged.

\section{References}

1. Kinoshita, J. H. 1990. A thirty year journey in the polyol pathway. Exp. Eye Res. 50:567-573.

2. Burg, M. B. 1988. Role of aldose reductase and sorbitol in maintaining the medullary intracellular milieu. Kidney Int. 33:635-641.

3. Bondy, C., B. D. Cowley, Jr., S. L. Lightman, and P. F. Kador. 1990. Feedback inhibition of aldose reductase gene expression in rat renal medulla. $J$. Clin. Invest. 86:1103-1108.

4. Ghahary, A., J. Luo, Y. Gong, S. Chakrabarti, A. A. Sima, and L. J. Murphy. 1989. Increased renal aldose reductase activity, immunoreactivity, and mRNA in streptozocin-induced diabetic rats. Diabetes. 38:1067-1071.

5. Ghahary, A., S. Chakrabarti, A. A. Sima, and L. J. Murphy. 1991. Effect of insulin and statil on aldose reductase expression in diabetic. Diabetes. 40:13911396.

6. Carper, D., M. Kaneko, H. Stark, and T. Hohman. 1990. Increase in aldose reductase mRNA in dog lens epithelial cells under hypertonic conditions. Exp. Eye Res. 50:743-749.

7. Fleming, D., and H. P. Pegler. 1963. The determination of glucose in the presence of maltos and isomaltose by a stable, specific enzymic reagent. Analyst. 88:967-968.

8. Gutmann, I., and A. W. Wahlefeld. 1974. L-(+)-lactate determination with lactate dehydrogenase and NAD. In Methods in Enzymatic Analysis. H. U. Bergmeyer, editor. Verlag Chemie, Weinheim and Academic Press, Inc., New York. 1464-1468.

9. Kulski, J. K., and G. D. Buehuring. 1982. Microanalysis of lactose in tissue culture medium using an enzymatic fluorometric method. Anal. Biochem. 119:341-350.

10. Arthur, P. G., J. C. Kent, and P. E. Hartman. 1989. Microanalysis of the metabolic intermediates of lactose synthesis in human milk and plasma using bioluiscent methods. Anal. Biochem. 176:449-456.

11. Stribling, D., D. J. Mirrless, H. E. Harrison, and D. C. N. Earl. 1985. Properties of ICI 128, 436, a novel aldose reductase inhibitor, it's effects on diabetic complication in the rat. Metab. Clin. Exp. 34:4, 336-343.

12. Dubois, M., K. A. Gilles, J. K. Hamilton, P. A. Rebers, and P. Smith 1956. Anal. Chem. 28:350-358.

13. Bradford, M. M. 1976. A rapid and sensitive method for the quantitation of microgram quantities of protein utilizing the principle of protein-dye binding. Anal. Biochem. 72:248-254.

14. Wermuth, B. 1985. Aldo-keto reductase. In Enzymology of Carbonyl Metabolism 2. T. G. Flynn and H. Weiner, editors. Alan R. Liss, Inc., New York. 209-230.

15. Kawasaki, N., T. Tanimoto, and A. Tanaka. 1989. Characterization of aldose reductase and aldehyde reductase from rat testis. Biochim. Biophys. Acta. 996:30-36.

16. Chomczynski, P., and N. Sacchi. 1987. Single-step method of RNA isolation by acid guanidinium thiocyanate-phenol-chloroform extraction. Anal. Biochem. 162:156-159.

17. Thomas, P. S. 1980. Hybridization of denatured RNA and small DNA fragment transferred to nitrocellulose. Proc. Natl. Acad. Sci. USA. 77:5201-5205.

18. Chung, S., and J. LaMendola. 1989. Cloning and sequence determination of human placental aldose reductase gene. J. Biol. Chem. 264:25, 14775-14777.

19. Quan-Ma, R., and W. W. Well. 1965. The distribution of galactitol in tissues of rats fed galactose. Biochem. Biophys. Res. Commun. 20:486-490.

20. Birlouez-Aragon, I., and S. Alloussi. 1990. Effect of prolonged galactose consumption on galactose consumption in young healthy humans. Ann. Nutr. Metab. 34:1-7.

21. Alloussi, S., I. Birlouez-Aragon, C. Fevrier, and H. Papadopoulos. 1989. Effects of 5\% galactose diet on galactose and dulcitol in plasma and lens of male and female pigs. Ann. Nutr. Metab. 33:323-329.

22. Lyons, P. A., S. Gould, P. H. Wise, and T. N. Palmer. 1991. Activation of erythrocyte aldose reductase in man in response to glycaemic challenge. Diabetes Res. Clin. Prac. 14:9-14.

23. Akagi, Y., P. F. Kador, and J. H. Kinoshita. 1987. Immunochemical localization for aldose reductase in diabetic lenses. Invest. Ophthalmol. Visual Sci. 28:163-167.

24. Lightman, S., C. Bondy, S. Lightman, and P. Kador. 1990. Aldose reductase messenger RNA in the lens epithelium in vivo: effects of diabetes mellitus and galactosaemia. Clin. Sci. 79:599-603. 